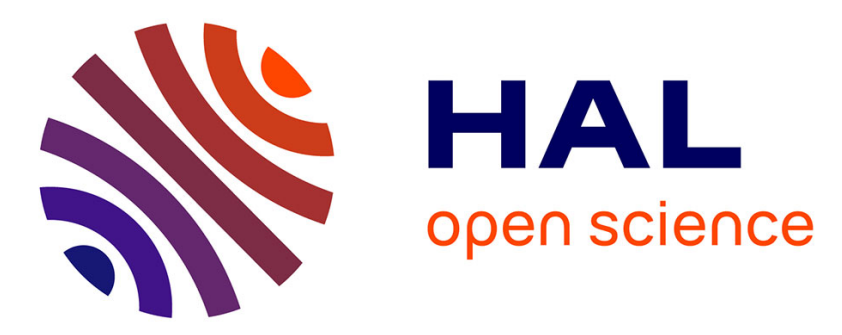

\title{
Extractives of the tropical wood wallaba (Eperua falcata Aubl.) as natural anti-swelling agents
}

Mariana Royer, Didier Stien, Jacques Beauchêne, Gaëtan Herbette, John Paul Mc Lean, Anne Thibaut, Bernard Thibaut

\section{- To cite this version:}

Mariana Royer, Didier Stien, Jacques Beauchêne, Gaëtan Herbette, John Paul Mc Lean, et al.. Extractives of the tropical wood wallaba (Eperua falcata Aubl.) as natural anti-swelling agents. Holzforschung, 2010, 64 (2), pp.211-215. 10.1515/HF.2010.034 . hal-01093227

\section{HAL Id: hal-01093227}

https://hal-agroparistech.archives-ouvertes.fr/hal-01093227

Submitted on 18 Jan 2019

HAL is a multi-disciplinary open access archive for the deposit and dissemination of scientific research documents, whether they are published or not. The documents may come from teaching and research institutions in France or abroad, or from public or private research centers.
L'archive ouverte pluridisciplinaire HAL, est destinée au dépôt et à la diffusion de documents scientifiques de niveau recherche, publiés ou non, émanant des établissements d'enseignement et de recherche français ou étrangers, des laboratoires publics ou privés. 


\section{Extractives of the tropical wood wallaba (Eperua falcata Aubl.) as natural anti-swelling agents}

\author{
Mariana Royer ${ }^{1}$, Didier Stien ${ }^{1, *}$, Jacques \\ Beauchêne $^{2}$, Gaëtan Herbette ${ }^{3}$, J. Paul McLean ${ }^{4}$, \\ Anne Thibaut ${ }^{2}$ and Bernard Thibaut ${ }^{1}$ \\ ${ }^{1}$ CNRS, UMR EcoFoG, Cayenne Cedex, France \\ ${ }^{2}$ Cirad, UMR EcoFoG, Kourou, France \\ ${ }^{3}$ Spectropole, Aix-Marseille Université, Faculté de Saint- \\ Jérôme, Marseille, France \\ ${ }^{4}$ Université Montpellier 2, Laboratoire de Mécanique et \\ Génie Civil, Montpellier, France \\ * Corresponding author. \\ CNRS, UMR Ecofog, Institut d'Enseignement Supérieur de la \\ Guyane, BP 792, 97337 Cayenne Cedex, France (French Guiana) \\ Phone: +594-594-297517 \\ Fax: +594-594-284786 \\ E-mail: didier.stien@guyane.cnrs.fr
}

\begin{abstract}
Wallaba (Eperua falcata) is a tropical wood that is known to have naturally high moisture related dimensional stability. Samples of wallaba heartwood were subjected to differential solvent extraction. Wood pieces that were extracted with methanol showed significantly greater swelling following rehydration from oven dry to $96 \%$ relative humidity than non-extracted samples and samples extracted with other solvents. Methanol soluble wallaba heartwood extract was purified by HPLC and the compounds present were characterized by NMR spectroscopy. The structure of 13 compounds in methanol extract was identified. The relative proportion of polar compounds in methanol extract was found to be high. The compounds identified are proposed to bind to the polymeric cell wall by means of multiple hydrogen bonds restricting the association of water and therefore act as natural anti-swelling agents.
\end{abstract}

Keywords: dimensional stability; Eperua falcata; extractives; HPLC; NMR; tropical wood.

\section{Introduction}

Wood cellulose is organized in crystalline networks within microfibrils coated by amorphous macromolecules of hemicelluloses and then by lignin. In wood cell walls, the organization of the layers of fiber composite and the orientation of the microfibrils are the determining factors of hygroscopic properties (Skaar 1988; Salmén and Burgert 2008). Dimen- sional variations in wood are induced by the adsorption and desorption of water, i.e., changes in wood moisture content (MC). Water is present in wood in two principal forms, commonly termed "bound water" and "free water'. Bound water is either intimately associated into the lignocellulosic network or linked to the wood cell wall through hydrogen bonding; in the latter case this is termed "water of saturation" or "water of surface absorption". Free water, sometimes termed 'interstitial water', is contained in cell lumens when the fiber saturation point (approximately 30\% wood $\mathrm{MC}$ ) is exceeded. The absorption or desorption of free water does not influence swelling of wood (U.S. Department of Agriculture 2007). However, removal or insertion of associated water influences the organization of wood macromolecules therefore inducing wood shrinkage or swelling (Skaar 1988).

There is a positive relationship between wood density and shrinkage. The study of the effect of wood density on shrinkage originates from Newlin and Wilson (1919) and is reviewed briefly with the other early literature in Chafe (1986). In general, wood density is a direct indicator of its anatomy (Fritts 1976) and therefore its porosity. Low density woods have low wood material per unit volume, thus proportionality less bound water and as such are relatively less affected by dimensional changes caused by changing MC than woods with higher density and proportionally more bound water. However, in addition to wood material, density can also be augmented by a group of extraneous chemicals linked to the formation of heartwood and collectively termed extractives. Extractives vary in quantity and composition by species (Hillis 1987; Xu et al. 2009). The presence of extractives has been shown by Hernandez (2007) to be significant in the deviation of tropical hardwoods from the normally positively correlated relationship of density and shrinkage. Hernandez (2007) expanded this empirical observation by deeming that the acetone and methanol extracted fractions of the studied material must contain the compounds located in the cell walls that inhibited swelling.

The objective of this study was to perform a detailed investigation into the effect of extractives on moisture related dimensional stability and the subsequent characterization of these compounds. Wood from wallaba (Eperua falcata Aubl., Caesalpiniaceae), a tropical rainforest species, was chosen as this species exhibits low shrinkage (radial 2.1\%; tangential $6.1 \%$; volumetric $10.1 \%$ ) during transformation from the green to the oven-dry state in spite of its high density of 0.86 $\mathrm{g} \mathrm{cm}^{-3}$ at $12 \% \mathrm{MC}$ (Gerard et al. 1996). The density of wallaba is undoubtedly influenced by a considerable extractive content, equal to $29 \%$ the dry weight (Amusant et al. 2007). 


\section{Material and methods}

\section{Sample collection and preparation}

An 80-cm log was collected from each of the two wallaba trees of approximately $40 \mathrm{~cm}$ diameter at breast height in Régina, French Guiana $\left(52^{\circ} 752^{\prime} / 4^{\circ} 1857^{\prime}\right)$. Boards of $2 \mathrm{~cm}$ in the radial dimension were cut from the logs to represent outer heartwood and inner heartwood. The boards were allowed to stabilize to equilibrium moisture content (EMC) in a continuously air-conditioned room before being split into bars of $20 \times 20 \mathrm{~mm}^{2}(\mathrm{R} \times \mathrm{T})$, then sliced lengthwise into samples of $20 \times 20 \times 10 \mathrm{~mm}^{3}(\mathrm{R} \times \mathrm{T} \times \mathrm{L})$. Low variations of wood in the longitudinal direction were assumed and therefore samples separated from the same rod were considered identical. In total, 72 wood pieces were produced from each tree for each radial position (i.e., outer heartwood and inner heartwood). These 72 wood pieces were separated into six groups of 12 longitudinally neighboring samples on which to perform extraction.

\section{Extraction of wood samples}

For each tree, five of the six groups of samples were placed in an Erlenmeyer flask, each with one of five extraction solvents: $300 \mathrm{ml}$ hexane, methylene chloride, ethyl acetate, methanol or water. The final group was left non-extracted to act as a control. The flasks were shaken at room temperature for 1 week. Expressed as percentage of mass of the dry samples, filtration and evaporation yielded the crude extracts of outer (hexane: $2.7 \%$; methylene chloride: 4.2\%; ethyl acetate: $6.9 \%$; methanol: $17.5 \%$; water: $2.1 \%$ ) and inner heartwood (hexane: $2.1 \%$; methylene chloride: $3.2 \%$; ethyl acetate: 6.1\%; methanol: $10.9 \%$; water: $1.2 \%$ ).

\section{Volumetric swelling of selectively extracted wood pieces}

Following extraction, all samples of the same group (12 pieces) were stored and air-dried at room temperature for 1 week, then dried over phosphorus pentoxide $\left(\mathrm{P}_{2} \mathrm{O}_{5}\right)$ in desiccators to near $1 \% \mathrm{MC}$. At this stage, a subgroup of three randomly selected samples from each group of 12 were conditioned in chambers at $32^{\circ} \mathrm{C}$ over saturated salt $\left(\mathrm{K}_{2} \mathrm{SO}_{4}, \mathrm{RH}=96 \%\right)$ for 10 days until they were deemed to have reached EMC of $19 \%$. The remaining nine samples from each group were stabilized at other MCs but are not described in this manuscript (for details see Royer 2008). Re-saturated samples were then weighed $\left(W_{H}\right)$ on a $0.1-\mathrm{mg}$ precision Sartorius balance and measured with $1 \mu \mathrm{m}$ precision Mitutoyo comparator, in the radial $\left(R_{H}\right)$ and tangential $\left(T_{H}\right)$ directions. Then, the pieces were oven-dried at $103^{\circ} \mathrm{C}$ for 2 days after which oven-dry mass $\left(W_{0}\right)$ as well as oven-dry radial $\left(R_{0}\right)$ and tangential $\left(T_{0}\right)$ dimensions were obtained in the same way. Length in the longitudinal direction was considered as constant allowing for calculation of volumetric swelling (S) as follows:

$S=\frac{R_{H} \times{ }_{T H}-\mathrm{R}_{0} \times \mathrm{T}_{0}}{\mathrm{R}_{0} \times \mathrm{T}_{0}} \times 100$

Whereas moisture content $(M C)$ was calculated as follows:

$$
M C=\frac{W_{H^{-}} \mathrm{W}_{0}}{\mathrm{~W}_{0}} \times 100
$$

\section{Statistical analysis}

The experiment contained two individual trees from which inferences of the population as a whole had to be drawn; it is unreasonable to assume that samples from the same tree were not related to each other. In short, the experimental design had both fixed (extraction and wood type) and random effects with a grouping factor. Following Pinheiro and Bates (2000), a linear mixed effects model (LME) was constructed with the form:

$\mathrm{G}_{\mathrm{ijkl}}=\mu+\tau_{i}+v_{j}+m c+A_{k}+\varepsilon_{l(k)}$

where $G_{i j k l}$ is the swelling of an individual sample, $\mu$ the overall mean, $\tau_{i}$ is the fixed effect of extraction $i(i=1,2 \ldots 6), v_{j}$ is the fixed effect of wood type $j(j=1,2), m c$ is the fixed effect of individual sample $\mathrm{MC}$ to account for small variations within the group, $A_{k}$ is the random effect of tree $k$ and $\varepsilon_{l(k)}$ is the random effect of sample $l$ from tree $k$. An interaction was considered between extraction and wood type.

The models were examined with an F-test in analysis of variance (ANOVA) with $\alpha=0.05$ level of significance to determine if the effects of extraction method were significant and if the effect was different depending on the type of wood. Models were constructed in the $\mathrm{R}$ open source environment (R-Core Development Team 2008) by means of ML (maximum likelihood theory) to fit LME. This is a technique suited to deliver balanced data and which allows for the comparison of models with different fixed effects. When the effect of extraction was found to be significant, two alternative LME models - with and without the fixed effect of extraction - were compared by a likelihood ratio test in ANOVA.

\section{Purification and characterization of extractives}

The only extract displaying anti-swelling efficiency was the one prepared by maceration of heartwood in methanol (see Figure 1 and Results section). Therefore, separation and chemical determination were performed for this extract only. The methanol extract was evaporated to residue on a rotary evaporator. HPLC equipment: Waters system equipped with a W600 pump and a W2996 photodiode array absorbance detector. HPLC details: Discovery ${ }^{\circledR} \mathrm{C} 18$ column $\left(250 \times 21.2 \mathrm{~mm}, 5 \mu \mathrm{m}\right.$, Supelco $\left.{ }^{\circledR}\right)$ with a linear gradient of $\mathrm{H}_{2} \mathrm{O} / \mathrm{CH}_{3} \mathrm{CN}$ starting with a relative proportion of 80:20 and changing over $10 \mathrm{~min}$ to pure $\mathrm{CH}_{3} \mathrm{CN}$. Flow rate: $15 \mathrm{ml} \mathrm{min}{ }^{-1}$; detection: at $300 \mathrm{~nm}$. NMR instrument: Bruker Avance DRX500 spectrometer $\left({ }^{1} \mathrm{H}-500.13 \mathrm{MHz}\right)$ equipped with a 5-mm triple resonance inverse cryoprobe TXI $\left({ }^{1} \mathrm{H}_{-}{ }^{13} \mathrm{C}_{-}{ }^{15} \mathrm{~N}\right)$, with $z$-gradient. Samples were placed in $1.7 \mathrm{~mm}$ NMR capillary tube in $40 \mu \mathrm{l}$ of $100 \% \mathrm{CD}_{3} \mathrm{OD}$ solvent $\left(\delta_{1 \mathrm{H}} 3.31 \mathrm{ppm}-\delta_{13 \mathrm{C}} 49.00 \mathrm{ppm}\right)$ at $300 \mathrm{~K}$. The pulse programs of all $1 \mathrm{D} / 2 \mathrm{D}$ experiments $\left({ }^{1} \mathrm{H},{ }^{13} \mathrm{C}\right.$-DEPTQ, COSY, NOESY, HMQC and $\mathrm{HMBC}$ ) were taken from the Bruker standard software library. Optical rotations were measured on a Perkin-Elmer model 241 polarimeter equipped with a sodium lamp (589 nm) and a 1-dm cell.

The compounds isolated were identified as:

- (土)-eperuic acid (1): $0.31 \%$ (Amusant et al. 2007; Marchesini et al. 2009). 1 is transparent in UV and was detected in HPLC fractions by TLC. It has been demonstrated in the literature that biosynthesis of labdane-type diterpenes might not be stereoselective (Fukuyama et al. 1999).

- Engeletin (2)/Isoengeletin (3) (2.3/1): 0.40\% (Xu et al. 2005; Yinrong and Yeap 1999). 


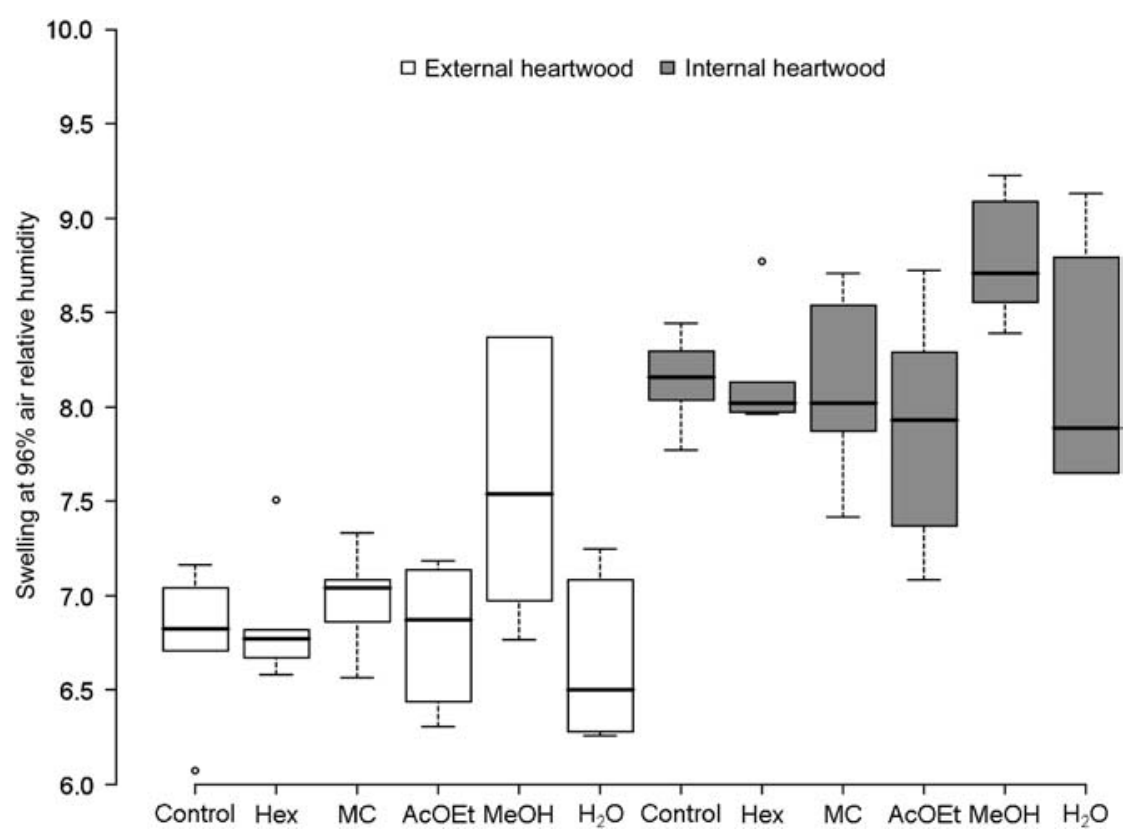

Figure 1 Wallaba heartwood swelling after extraction and rehydration from oven dry to 19\% wood moisture content. Control, no extraction; Hex, hexane; $\mathrm{MC}$, methylene chloride; AcOEt, ethyl acetate; $\mathrm{MeOH}$, methanol and $\mathrm{H}_{2} \mathrm{O}$, water. The methanol extracted samples displayed significantly higher swelling than the other extraction methods $(\alpha=0.05)$. Internal heartwood samples had significantly higher swelling than external heartwood samples.

- Neoengeletin (4)/Neoisoengeletin (5) (8.3/1): 0.22\% (Gaffield et al. 1975).

- Astilbin (6)/Neoastilbin (7) (1.2/1): 0.15\% (Gaffield et al. 1975; Xu et al. 2005).

- $p$-Hydroxybenzoic acid (8): 0.09\%.

- Gallic acid (3,4,5-Trihydroxybenzoic acid, 9): 0.16\% (Saito and Kawabata 2006).

- (+)-Catechin (10)/(-)-Epicatechin (11) (1/1.5): 1.09\% (Nay et al. 2001; Mendoza-Wilson and Glossman-Mitnik 2006). Absolute configurations were tentatively assigned based on optical rotation of epicatechin derivative 12, assuming that $\mathbf{1 2}$ should be a derivative of wallaba epicatechin.

- (-)-3-(4-Hydroxybenzoyl)epicatechin (12): $1.02 \%,[\alpha]_{\mathrm{D}}{ }^{20}-38.4^{\circ}$ (c 0.012, MeOH) (Watanabe 1998).

- (-)-Dihydrokaempferol (13): $0.41 \%,[\alpha]_{\mathrm{D}}^{20}-56.3^{\circ}$ (c 0.009 , $\mathrm{MeOH})$ (Yinrong and Yeap 1999).

In all cases, yields reported are those obtained for the fraction used for structural elucidation. Isolation yields are not quantitative owing to extensive overlap of HPLC peaks, particularly for compounds $2-7$. Identifications were confirmed based on literature data.

\section{Results}

\section{Swelling}

Wallaba wood pieces were extracted with different solvents and after rehydration to a mean wood MC of $19.04 \%$ $(\mathrm{SD}=0.78 \%)$. The volumetric swelling was measured and compared with non-extracted wood pieces as reference (Figure 1). The relative significance of parameters was assessed by ANOVA of the linear mixed effects model in Eq. (3) and results are listed in Table 1.

In Figure 1, it is clear that the samples extracted by methanol exhibited greater swelling than samples from both the control and the other extraction methods. ANOVA showed that variation in individual sample $\mathrm{MC}$ had the most significant effect $\left(\mathrm{F}_{1,58}=93.25, p<0.001\right)$ followed by wood type $\left(\mathrm{F}_{1,58}=61.94, p<0.001\right)$ and then extraction $\left(\mathrm{F}_{5,58}=6.73\right.$, $p<0.001$ ) (Table 1). A likelihood ratio comparison of the two alternate models for swelling fitted with and without the effect of extraction showed the inclusion of extraction in the model to be significant $(p=0.0013)$. An examination of the model estimates showed that the samples that were extracted with methanol displayed significantly greater swelling than the control and the other methods of extraction $(\alpha=0.05)$. The interaction term between extraction and wood type was not significant $\left(\mathrm{F}_{5,58}=0.76, p=0.589\right)$ which shows that the method of extraction did not have a different effect depending on wood type. When the difference between means was examined, internal heartwood samples extracted in methanol had swollen on average $0.63 \%$ (actual not percentage difference) more than the control, whereas the external heartwood samples had swollen on average $0.82 \%$ more than the control. Mean wood density of the internal heartwood samples was $0.82 \mathrm{~g} \mathrm{~cm}^{-3}\left(\mathrm{SD}=0.03 \mathrm{~g} \mathrm{~cm}^{-3}\right)$ before extraction and $0.74 \mathrm{~g} \mathrm{~cm}^{-3}\left(\mathrm{SD}=0.03 \mathrm{~g} \mathrm{~cm}^{-3}\right)$ after methanol extraction. Mean wood density of the external heartwood samples was $0.82 \mathrm{~g} \mathrm{~cm}^{-3}\left(\mathrm{SD}=0.02 \mathrm{~g} \mathrm{~cm}^{-3}\right)$ before extraction and $0.69 \mathrm{~g}$ $\mathrm{cm}^{-3}\left(\mathrm{SD}=0.03 \mathrm{~g} \mathrm{~cm}^{-3}\right)$ after methanol extraction. 
Table 1 Analysis of variance of the linear mixed effects model to determine the significance of extraction method and wood type (inner or outer heartwood) on the swelling of rehydrated oven-dry wallaba wood samples.

\begin{tabular}{lccrr}
\hline \multicolumn{1}{c}{ Coefficient } & $\begin{array}{c}\text { Numerator } \\
\text { d.f. }\end{array}$ & $\begin{array}{c}\text { Denominator } \\
\text { d.f. }\end{array}$ & F-value & $p$-Value \\
\hline Individual & 1 & 58 & 93.2458 & $<0.0001$ \\
Moisture content & 5 & 58 & & \\
$\quad$ Extraction & 1 & 58 & 6.7301 & 0.0001 \\
$\quad$ Wood type & 5 & 58 & 0.7524 & $<0.0001$ \\
Extraction $\times$ wood type & & & 0.5858 \\
\hline
\end{tabular}

d.f. is degrees of freedom.

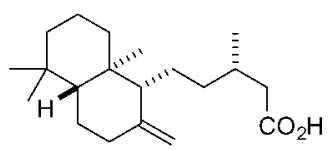

( \pm )-Eperuic acid (1):0.31\%<smiles>[R6]OC1C(=O)c2c(O)cc(O)cc2OC1c1ccc(O)c([R])c1</smiles>

Engeletin (2): $2 R, 3 R, \mathrm{R}=\mathrm{H}$ Isoengeletin (3): $2 R, 3 \mathrm{~S}, \mathrm{R}=\mathrm{H}\} 2.3: 1(0.40 \%)$ $\left.\begin{array}{l}\text { Neoengeletin (4): } 2 S, 3 S, \mathrm{R}=\mathrm{H} \\ \text { Neoisoengeletin (5): } 2 S, 3 R, \mathrm{R}=\mathrm{H}\end{array}\right\} 8.3: 1(0.22 \%$ Neoisoengeletin (5): $2 S, 3 R, \mathrm{R}=\mathrm{H}$ $\left.\begin{array}{l}\text { Astilbin (6): } 2 R, 3 R, \mathrm{R}=\mathrm{OH} \\ \text { Neoastilbin (7): } 2 S, 3 S, \mathrm{R}=\mathrm{OH}\end{array}\right\} 1.2: 1(0.15 \%)$<smiles>[R]c1cc(C(=O)O)cc([R])c1O</smiles>

8: $\mathrm{R}_{1}=\mathrm{R}_{2}=\mathrm{H}(0.09 \%)$ 9: $\mathrm{R}_{1}=\mathrm{OH}, \mathrm{R}_{2}=\mathrm{OMe}(0.16 \%)$<smiles>[R]C1Cc2c(O)cc(O)cc2OC1c1ccc(O)c(O)c1</smiles>

(+)-Catechin (10): $\left.2 R, 3 S, \mathrm{R}_{1}=\mathrm{OH} \quad\right\}$ 1:1.5 (1.09\%) (-)-Epicatechin (11): $2 R, 3 R, \mathrm{R}_{1}=\mathrm{OH}$
(-)-12: $2 R, 3 R, \mathrm{R}_{1}=p$-hydroxybenzoate $(1.02 \%)$<smiles>O=C1c2c(O)cc(O)cc2O[C@@H](c2ccc(O)cc2)[C@@H]1O</smiles>

(-)-Dihydrokaempferol (13) (0.41\%)

Figure 2 Molecules isolated in methanol extract of outer and inner heartwood of Eperua falcata (Rha= $\alpha$-L-Rhamnopyranosyl).

\section{Characterization of extractives}

Wallaba heartwood extractives were purified and separated on HPLC, whereby the chromatograms were found to be identical, in terms of composition, for internal and external heartwood (data not shown). Extractives were then identified by NMR spectroscopy, with identifications verified by published literature. Characterization allowed us to establish that the active extract contains 13 main compounds represented in Figure 2.

\section{Discussion}

Methanol is the most efficient solvent for the chemical extraction of wallaba wood because it removes the highest percentage of extractives. Its intermediate polarity makes it capable of extracting compounds usually insoluble in water or less polar solvents. The extraction of methanol soluble compounds increased the swelling of oven-dry wallaba wood pieces subjected to elevated ambient relative humidity. This result is consistent with the phenomenon observed by Hernandez (2007) who demonstrated that the extractives which induce wood swelling are soluble in polar solvents such as acetone or methanol. In this study, the wallaba samples obtained from the internal heartwood had swollen more than those from the external heartwood. This radial variability in the heartwood has been described before for two shortleaf pine trees (Choong and Fogg 1989). The difference between outer and inner heartwood might be linked to quantitative differences in extractive content (Lacandula 2002) and the resulting effect on wood density (Hernandez 2007). The current results can be considered as further evidence. The nonextracted internal heartwood samples swelled more than the non-extracted external heartwood samples, although they had the same density. The reason for this is the lower extractive content of the former $(10.9 \%$ compared with $17.5 \%$ of the latter). Then, following methanol extraction, internal heartwood samples exhibited greater swelling than the external heartwood samples because they had higher density $(0.74 \mathrm{~g}$ $\mathrm{cm}^{-3}$ compared with $0.69 \mathrm{~g} \mathrm{~cm}^{-3}$ ). Thus, our results both conform to the original theory of Newlin and Wilson (1919), where density and shrinkage (or swelling) are positively correlated and, moreover, confirm that the dimensional stability is proportional to the content of extractives.

In the light of this information, we embarked upon analyzing and quantifying those wood extractives soluble in methanol to better understand the mechanisms involved in 
their natural inhibition of shrinkage. Overall, methanol is able to dissolve a wide range of compounds from wood. In the mixture, the major constituents are polyphenols (compounds 8-13, 2.8\% cumulated yield) and glycosylated polyphenols (compounds 2-7, $0.8 \%$ cumulated yield). These compounds are all very polar and presumably likely to associate with the cell wall in amorphous regions of the macromolecules network, thereby contributing to the supramolecular organization of the network and competing with water absorption. This phenomenon was originally proposed by Shupe et al. (1996) to account for hysteresis effect observed in the dimensional changes of the wood from sweetgum (Liquidambar styraciflua L.) trees, although the quoted authors did not characterize the compounds responsible for this property. Our study seems to confirm the hypothesis of Shupe et al. (1996) and further proves that extractives are indeed capable of interacting with the wood cell wall to influence swelling/shrinking behavior.

\section{References}

Amusant, N., Moretti, C., Richard, B., Prost, E., Nuzillard, J.M., Thévenon, M.F. (2007) Chemical compounds from Eperua falcata and Eperua grandiflora heartwood and their biological activities against wood destroying fungus (Coriolus versicolor). Holz Roh Werkst. 65:23-28.

Chafe, S.C. (1986) Collapse, volumetric shrinkage, specific gravity and extractives in Eucalyptus and other species. Part 1: the shrinkage/specific gravity ratio. Wood Sci. Technol. 20:293307.

Choong, E.T., Fogg, P.J. (1989) Differences in moisture content and shrinkage between innerwood and outerwood of two shortleaf pine trees. For. Prod. J. 39:13-18.

Fritts, H.C. Tree Rings and Climate. Academic Press, London, 1976.

Fukuyama, Y., Yokoyama, R., Ohsaki, A., Takahashi, H., Minami, H. (1999) An example of the co-occurrence of enantiomeric labdane-type diterpenes in the leaves of Mimosa hostilis. Chem. Pharm. Bull. 47:454-455.

Gaffield, W., Waiss, A.C., Tominaga, T. (1975) Structural relations and interconversions of isomeric astilbins. J. Org. Chem. 40: $1057-1061$.

Gérard, J., Miller, R.B., Welle, B.J.H. (1996) Major timber trees of Guyana: timber characteristics and utilization. In: Tropenbos Series 15. The Tropenbos Foundation, Wageningen.

Hernandez, R.E. (2007) Swelling properties of hardwoods as affected by their extraneous substances, wood density, and interlocked grain. Wood Fiber Sci. 39:146-158.

Hillis, W.E. Heartwood and Tree Exudates. Springer-Verlag, Berlin, 1987.

Lacandula, J.O. (2002) Variations in the physics of wood of selected
Philippine tree species as a function of extractive content. CMU J. Sci. 10:69-111.

Marchesini, A.M., Prado, G.G., Messiano, G.B., Marcos, B., Machado, M.B., Lopes, L.M.X. (2009) Chemical constituents of Aristolochia giberti. J. Braz. Chem. Soc. 20:1598-1608.

Mendoza-Wilson, A.M., Glossman-Mitnik, D. (2006) Theoretical study of the molecular properties and chemical reactivity of (+)catechin and (-)-epicatechin related to their antioxidant ability. J. Mol. Struct.: Theochem 761:97-106.

Nay, B., Arnaudinaud, V., Vercauteren, J. (2001) Gram-scale production and applications of optically pure ${ }^{13} \mathrm{C}$-labelled (+)-catechin and (-)-epicatechin. Eur. J. Org. Chem. 2379-2384.

Newlin, J.A., Wilson, T.R.C. (1919) The relation of shrinkage and strength properties of wood to its specific gravity. USDA For. Prod. Lab. Bull. 676:1-35.

Pinheiro, J.C., Bates, D.M. Mixed Effects Model in S and S-plus. Springer, New York, 2000.

Royer, M. Molécules responsables de la stabilité du bois: cas des bois tropicaux de Guyane. PhD thesis. Université des Antilles et de la Guyane, Cayenne, 2008.

Saito, S., Kawabata, J. (2006) DPPH (=2,2-diphenyl-1-picrylhydrazyl) radical-scavenging of protocatechuic acid ( $=3,4$-dihydroxybenzoic acid): difference in reactivity between acids and their esters. Helv. Chim. Acta 89:1395-1407.

Salmén, L., Burgert, I. (2008) Cell wall features with regard to mechanical performance. A review. COST Action E35 2004-2008: Wood machining - micromechanics and fracture. Holzforschung 63:121-129.

Shupe, T.F., Choong, E.T., Gibson, M.D. (1996) The effects of previous drying and extractives on the radial and tangential shrinkage of outerwood, middlewood, and corewood of two sweetgum trees. For. Prod. J. 46:94-97.

Skaar, C. Wood-Water Relations. Springer-Verlag, New York, 1988.

U.S. Department of Agriculture. The Encyclopedia of Wood. Skyhorse Publishing, Washington, DC, 2007.

Watanabe, M. (1998) Catechins as antioxidants from Buckwheat (Fagopyrum esculentum Moench) groats. J. Agric. Food Chem. 46:839-845.

Xu, J., Li, X., Zhang, P., Li, Z.L., Wang, Y. (2005) Antiinflammatory constituents from the roots of Smilax bockii Warb. Arch. Pharm. Res. 28:395-399.

Xu, C., Pranovich, A., Hemming, J., Holmbom, B., Albrecht, S., Schols, H.A., Willför, S. (2009) Hydrolytic stability of watersoluble spruce O-acetyl galactoglucomannans. Holzforschung 63:61-68.

Yinrong, L., Yeap, F.L. (1999) The polyphenol constituents of grape pomace. Food Chem. 65:1-8.

Received June 22, 2009. Accepted October 16, 2009.

Previously published online January 14, 2010. 